\title{
Spontaneous Vascular Mineralization in the Brain of Aged B6C3F1 Mice
}

\author{
Tokuma YANAI, Kazuo KUDO, Jun MANABE, and Naochika MATSUNUMA \\ Laboratory Animal Science and Toxicology Laboratories, Sankyo Co., Fukuroi, Shizuoka 437, Japan
}

(Received 3 April 1984/Accepted 26 June 1984)

\begin{abstract}
The incidence of spontaneous mineralization in the brain of aged B6C3F1 mice and its histopathological and ultrastructural features were studied. Mineralized foci were observed in the wall of small blood vessels of the thalamus. They varied in shape and size and were positive for von Kossa stain. Ultrastructurally, electron dense deposit were shown in the thickened basement membrane. The lesions were detected first at 58 weeks of age and the incidence and the severity were higher in aged animals.-Key words: brain, $\mathrm{B} 6 \mathrm{C} 3 \mathrm{~F} 1$ mice, mineralization.
\end{abstract}

Jpn. J. Vet. Sci. 46(5): 761-765, 1984

B6C3F1 mice have been widely used for studying chemical carcinogenicity. In the course of bioassay of carcinogenicity using B6C3F1 mice, spontaneous mineralization was frequently observed in the brain of aged animals, as has been reported in several strains of mice [4-7, 9-11]. Though Ward et al. [10] briefly mentioned the incidence of brain mineralization in $\mathrm{B} 6 \mathrm{C} 3 \mathrm{~F} 1$ mice, the localization, age-related incidence and severity of the lesion have not been clear.

This report deals with histopathological and ultrastructural characteristics and agerelated incidence of mineralization in the brain of $\mathrm{B} 6 \mathrm{C} 3 \mathrm{~F} 1$ mice.

Seventy-five male and 73 female of B6C3F1 mice, 4 weeks of age were purchased from commercial breeder (Charles River Japan, Atsugi) and maintained for 105 weeks as untreated controls of a carcinogenicity testing. All animals were housed individually at $22-24^{\circ} \mathrm{C}$ and relative humidity of $44-45 \%$ and they were provided with a commercial powdered feed (CMF: Oriental Yeast Co., Tokyo) and water ad libitum.

Animals were sacrificed at $32,58,84,109$ weeks of age. Brains were collected and fixed in $10 \%$ buffered formalin, sectined at
$5 \mu \mathrm{m}$, and stained with hematoxylin and eosin (HE). Selected sections were also stained with periodic acid-Schiff (PAS), alizarin red, von Kossa and Perls stain methods.

From four mice, 109 weeks of age, brains were removed and fixed with $4 \%$ glutaraldehyde ( $\mathrm{pH} 7.4$ ), postfixed with $1 \%$ osmium tetroxide ( $\mathrm{pH} 7.2)$, and embedded in Epon 812. Ultrathin sections were made and stained with uranyl acetate and lead nitrate and examined with a JEM $100 \mathrm{C}$.

No macroscopic lesion was detected in the brain of all mice examined, while tumors of the liver and the hematopoietic system were

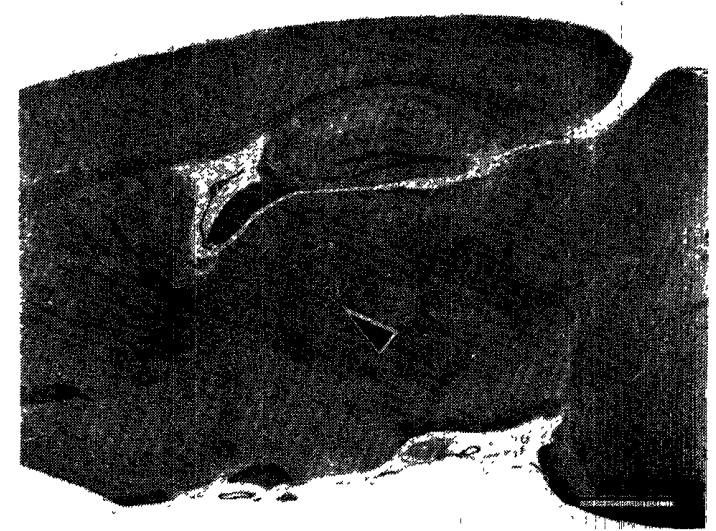

Fig. 1. Lesions (arrow head) in blood vessels of the thalamus. 109-week-old male. HE. Bar $=1 \mathrm{~mm}$. 
common in older $\mathrm{B} 6 \mathrm{C} 3 \mathrm{~F} 1$ mice as already described [10].

By light microscopy, mineralized lesions without inflammatory reactions were found focally at the wall of small blood vessels in the thalamus, mostly in the ventral thalamic nuclei (Fig. 1). The lesions varied in shape and size, approximately $56 \mu \mathrm{m}$ in diameter on average with a concentric lamellar structure (Figs. 2 and 3). The deposits were stained dark blue to violet with $\mathrm{HE}$ and positive for PAS reaction. With von Kossa stain calcium

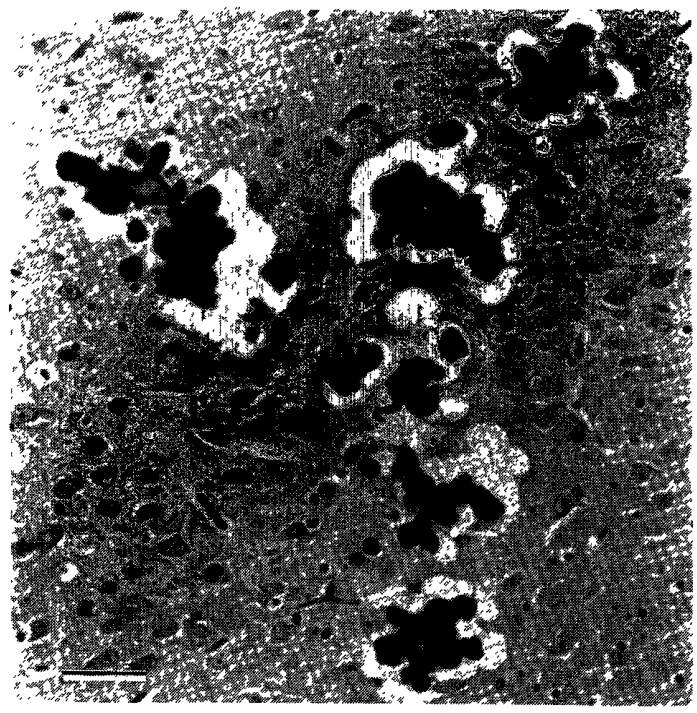

Fig. 2. Multiple foci, resembling "psammuma bodies", vary in shape and size from the same brain shown in Fig. 1. HE. Bar $=50 \mu \mathrm{m}$.

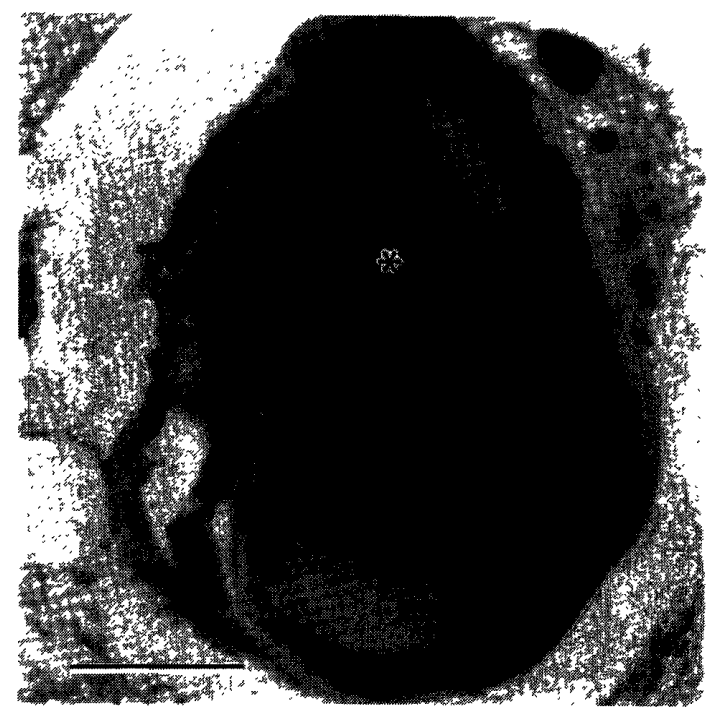

Fig. 3. A deposit (*) with a concentric, lamellar structure. HE. Bar $=10 \mu \mathrm{m}$. was demonstrable as dark brown crystals in the deposits, which were also positive for alizarin red (Fig. 4). Some deposits were weakly positive for iron with Perls stain. Sometimes the lumen of small blood vessel was occupied by protruded deposits and the wall was compressed (Fig. 3). In severe cases, these lesions resembled "psammoma bodies" (Fig. 2).

By electron microscopy, electron dense materials were focally deposited in the basement membrane of small blood vessels of the thalamus. The deposits, round in shape and varing in size, were present mostly in the subendothelial area (Figs. 5 and 6). In smaller deposits, a concentric circle structure with light and dark alternation was evidenced (Fig. 5), while larger deposits were rather homogenous with some fine granular appearance (Fig. 6). Small needle-like crystals seemed to be initial lesions of the basement membrane (Figs. 7 and 8 ). The vascular wall with mineralization was arteriosclerotic. Moderate or severe thickening of the basement membrane and atrophy of some endothelial cells with increased electron density were observed (Figs. 5-8). In most of severely mineralized blood vessels the lumen was stenotic (Figs. 5 and 6).

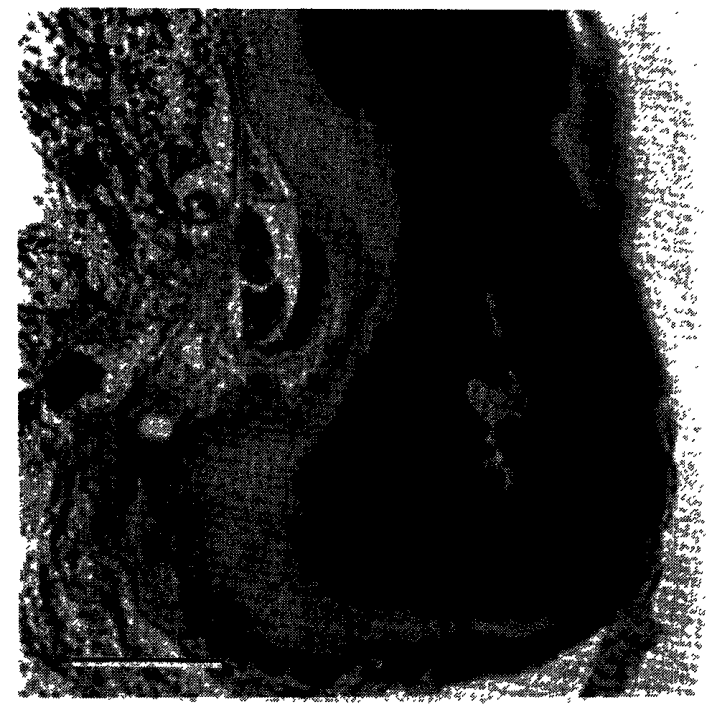

Fig. 4. Deposit positive for von Kossa stain. Bar= $10 \mu \mathrm{m}$. 


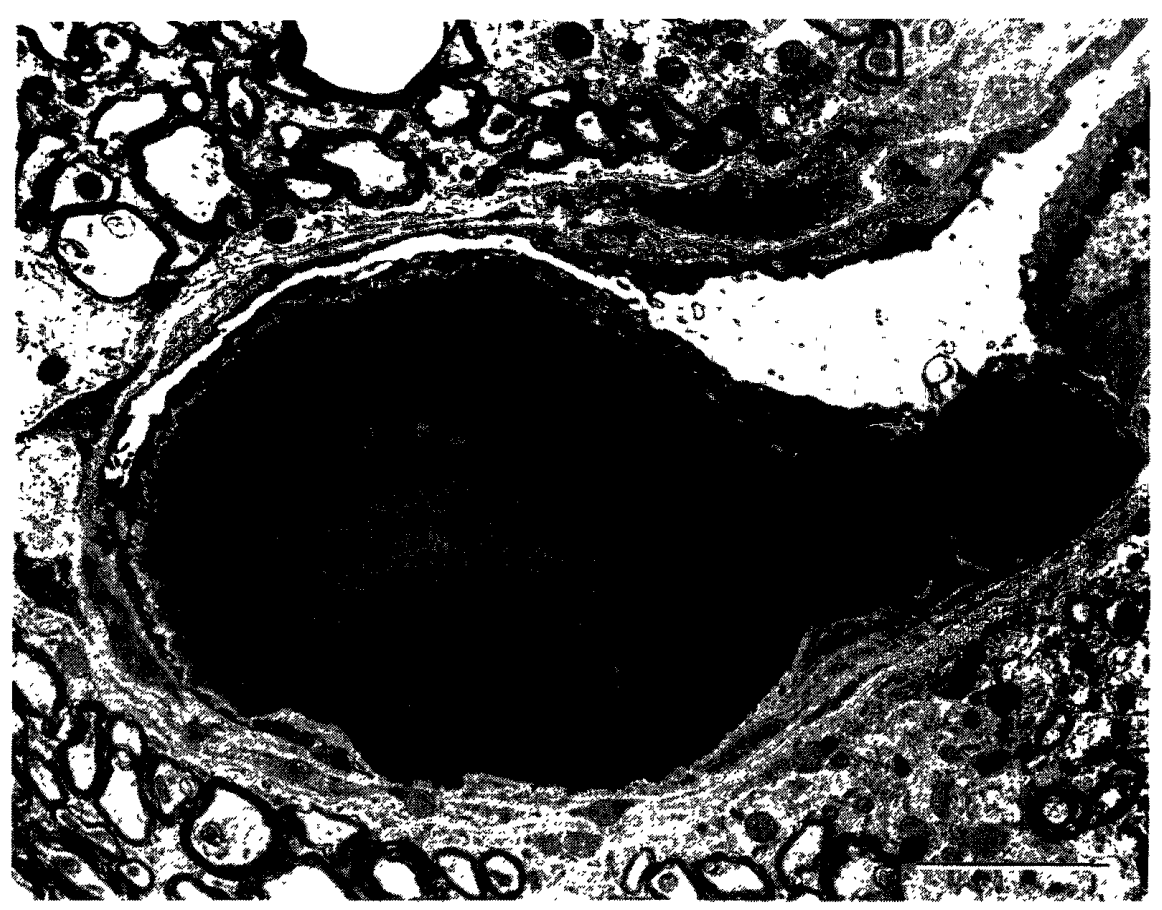

Fig. 5. Deposition of electron dense material in the basement membrane of a small blood vessel, showing a concentric circle structure. Bar $=5 \mu \mathrm{m}$.

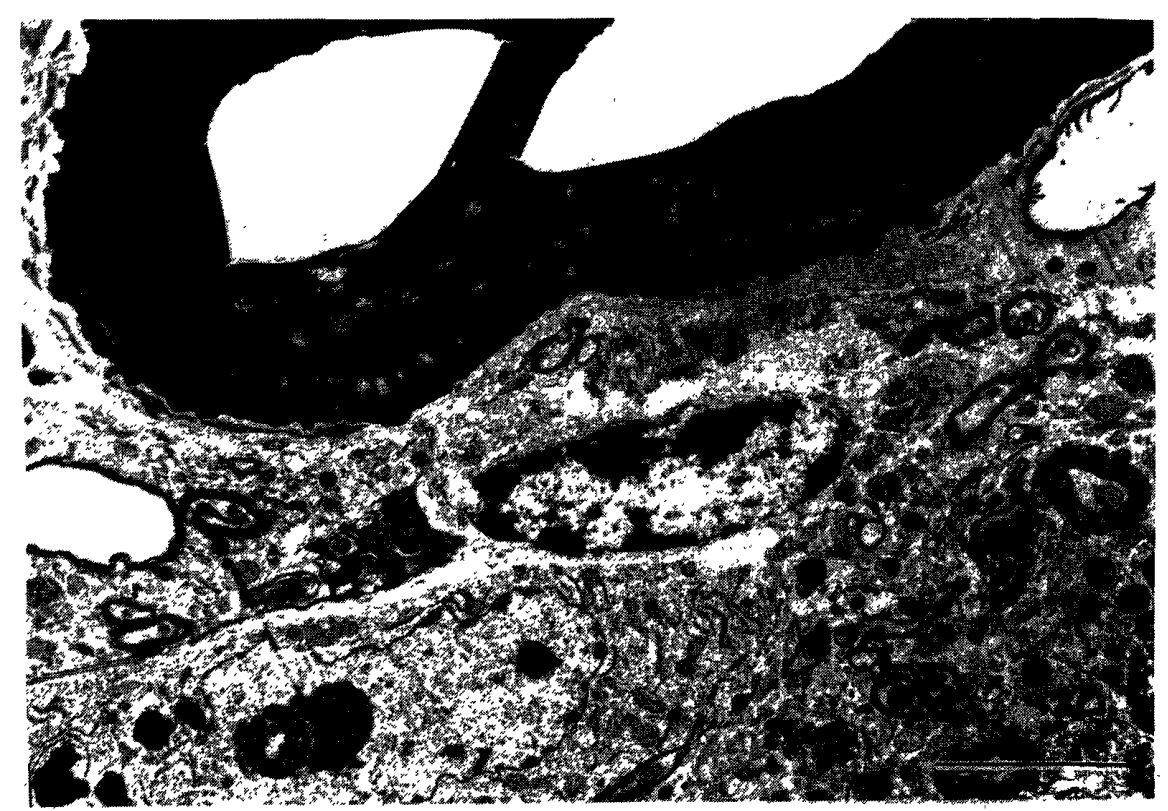

Fig. 6. Larger deposit, being electron dense and homogenous with fine granules. $\mathrm{Bar}=5 \mu \mathrm{m}$.

Tremor, convolution and hypersensitiveness were often observed in males but not in females after 84 weeks of age. However, there was no apparent association between these clinical signs and mineralized lesions in the brain. Mice showing neurological signs did not always have mineralized lesions in the brain.

Mineralized lesins in the brain was observed already in case examined at 58 weeks of age, increasing in incidence and severity (Table 1). There was a slight difference in incidence and severity of lesions between male and female mice. 


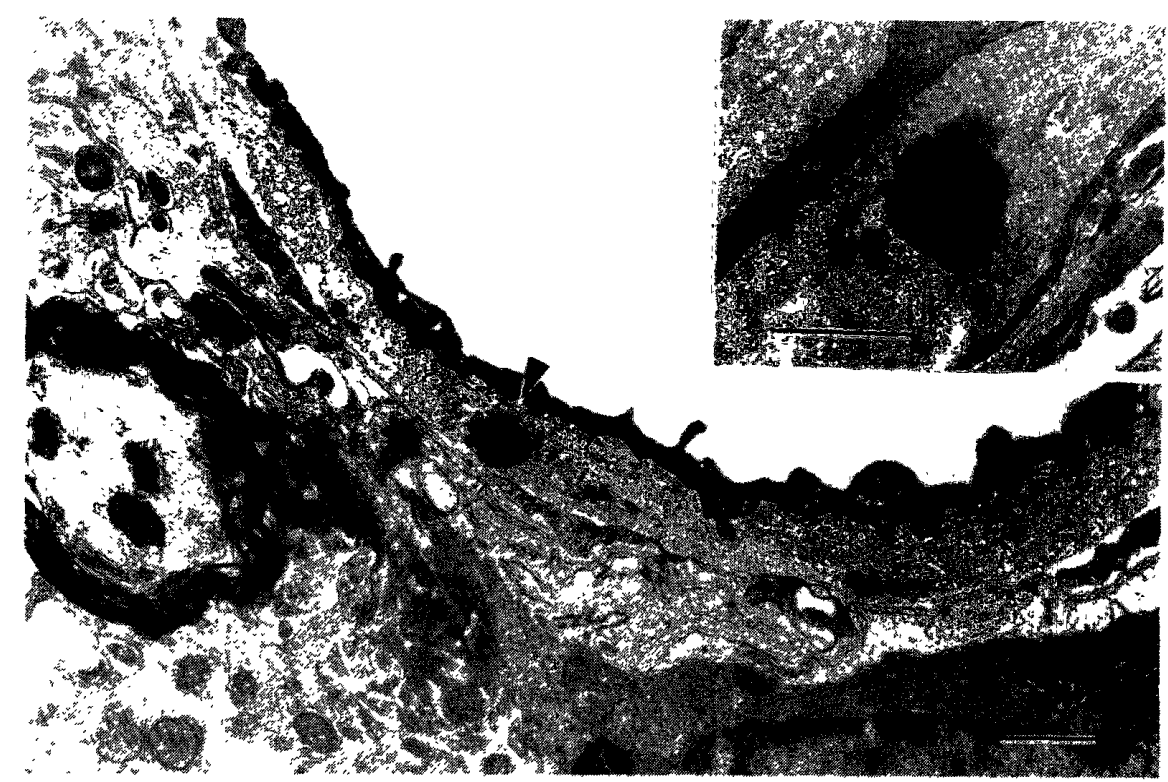

Fig. 7 and 8. A small focal deposit of electron dense material, probably at an initial stage of mineralization (arrow head), in the moderately thickened basement membrane. $\operatorname{Bar}=1 \mu \mathrm{m}$.

Table 1. Incidence of mineralization in the brain blood vessels of $\mathrm{B} 6 \mathrm{C} 3 \mathrm{~F} 1$ mice

\begin{tabular}{cccc}
\hline \multirow{2}{*}{$\begin{array}{l}\text { Age in } \\
\text { weeks }\end{array}$} & \multicolumn{3}{c}{ Affected } \\
\cline { 2 - 4 } & Male & Female & Total (\%) \\
\hline 32 & $0 / 5^{\text {a) }}$ & $5 / 5$ & $0 / 10$ \\
58 & $3 / 5$ & $1 / 5$ & $4 / 10(40.0)$ \\
84 & $7 / 11$ & $5 / 10$ & $12 / 21(57.1)$ \\
109 & $38 / 54$ & $28 / 53$ & $66 / 107(61.7)$ \\
\hline
\end{tabular}

a) Number affected/Number examined.

Spontaneous mineralizations without inflammatory responses in blood vessels of the brain thalamus has been described in several strains of mice [4-7, 9-11]. The deposits were intensely positive for PAS [10] and von Kossa stain [4]. Histological features of the present cases were similar to those described previously. Though Yoshii et al. [11] reported that the deposits were negative for von Kossa stain after fixation with Bouin or Tellyniczky solution, this might be due to inadequate fixations for the staining for calcium.

Electron microscopy suggested that the lesions were initiated with a focal deposition of an electron dense calcium-containing substance in the basement membrane following some arteriosclerotic change of the vascular wall.

Ward et al. [10] reported the much lower incidence than in the present cases, being 6.2 and $5.2 \%$ in males and females, respectively, of B6C3F1 mice over 90 weeks of age. Fraser et al. [4] observed such lesions in 34 out of 2000 mice of several strains, 279 to 827 days of age. Frith et al. [5] also found similar lesions in $7.5 \%$ of male and $2.7 \%$ of female BALB/c mice as well as $9.4 \%$ of male and $6.1 \%$ female C57BL/6 mice over 500 days of age. Since the lesions were localized very small regions of the brain, difference in the site of sectioning might result in the discrepancy between the authors. On the other hand, the difference in genetic background, rearing environment and diet might be another factor.

Spontaneous dystrophic epicardial mineralization was observed in certain inbred strains of mice [1-3] and genetic, hormonal and dietary factors were described to be related with the incidence and the severity of lesions [1-3]. There was no evidence of these influences on mineralized lesions in the brain of mice in concern. 
The cause of mineralized lesions remain unclear. In human, an autogenous calcium and iron deposits in and around small blood vessels of the globus pallidus has been described as vascular siderosis or calcinosiderosis [8]. This occurs in about $80 \%$ of subjects over 70 years old in frequent association with arteriosclerosis. The present mouse cases might provide useful models for human diseases.

AKNOWLEDGEMENT. The authors wish to thank Prof. Kôsaku Fujiwara, Faculty of Agriculture, University Tokyo, for reviewing and correcting the manuscript.

\section{REFERENCES}

1. Ball, C. R., and Williams, W. L. 1965. Anat. Rec. 152: 199-203.

2. Brownstein, D. G. 1983. Lab. Anim. Sci. 33: 247-248.

3. Eaton, G. J., Custer, R. P., Johnson, F. N., and Stabenow, T. K. 1978. Am. J. Pathol. 90: 173-
182.

4. Fraser, H. 1968. J. Pathol. Bacteriol. 96: 220222.

5. Frith, C. H., Highman, B., Burger, G., and Sheldon, W. D. 1983. Lab. Anim. Sci. 33: 273286.

6. Jortner, B. S., and Percy, D. H. 1978. pp. 319-421. In: Pathology of laboratory animals (Benirschke, K., Garner, F. M., and Jones, T. C. eds.). Springer-Verlag, New York.

7. Sheldon, W. D., and Greenman, D. L. 1979. pp. 155-167. In: Innovations in cancer risk assessment(ED01 study). (Staffa, J. A., and Mehlman, M. A. eds.). Pathotox Publ., Illinois.

8. Stehbens, W. E. 1972. pp. 592-632. In: Pathology the cerebral blood vessels. The C. V. Mosby Co., Saint Louis.

9. Tucker, M. J., and Baker, S. B. 1967. pp. 787-824. In: Pathology of laboratory rats and mice(Cortchin, E., and Roe, F. J. C. eds.). Blackwell Scientific Publications, Oxford.

10. Ward, J. M., Goodman, D. G., Squire, R. A., Chu, K. C., and Linhart. M. S. 1979. JNCI. 63: 849-854.

11. Yoshii, Y., and Phillips, T. L. 1983. Lab. Anim. Sci. 33: 66-69.

\section{要約}

老齢 $\mathrm{B} 6 \mathrm{C} 3 \mathrm{~F} 1$ マウスの脳小血管に抢访る自然発生釷物質沈着症（短報）：柳井徳磨・工藤和男・真鍋 淳・松 沼尚史 (三共(株) 安全性研究所)—58週齢以上の $\mathrm{B} 6 \mathrm{C} 3 \mathrm{~F} 1$ マウスの脳化認められた釷物質沈着症の加龄に伴う 発生頻度, 病理組織学的および電顕的特徵について検討した。発生頻度と程度は加齢に伴って增強する傾向を示 した。沈着巣は視床の小血管壁化認められ，形と大きさは種々で，von Kossa 染色で陽性を示した。電顕的には 小血管の肥厚した基底膜に高電子密度の物質が沈着していた。 